| SBAD | Gaziosmanpaşa Üniversitesi Sosyal Bilimler Araştırmaları Dergisi

Gaziosmanpasa University Social Sciences Researches Journal

(Kış 2017) 12/2: 31-52/ (Winter 2017) 12/2: 31-52

Makale Geliş Tarihi: 12.06.2017 Yayın Kabul Tarihi: 09.10.2017

Doi Number : http://dx.doi.org/10.19129/sbad.328

\title{
SAMSUN'DA BİR BATILILAŞMA ÖRNEĞİ: ESKİ BELEDİYE SARAYI*
}

\section{Serpil SEYFI ${ }^{* *}$-Ahmet Ali BAYHAN ${ }^{* * *}$}

Bu çalışmada XIX. yüzyıldan itibaren batılılaşmanın Anadolu'daki bir örneği olan Samsun Eski Belediye Sarayı'nın tarihi, mimarisi ve cephe tasarımları değerlendirilmiş ve yapının cephe tasarımlarında hâkim olan üslupların neler olduğu ve yapıda meydana getirdiği değişiklikler üzerinde durulmuştur.

Tanzimat reformuyla birlikte Batılılaşma sürecine giren Osmanlı Devleti'nin Anadolu'daki önemli liman kentlerinden biri olan Samsun şehrinde ticari ilişkiler, içerisinde bulunduğu nüfus yapısı, Levantenlerin ve yabancı mimarların faaliyetleri doğrultusunda kamu binaları ve diğer yapı türleri klasik anlayıştan uzaklaşarak, tasarım alanında üslup bakımından değişikliklere gitmeye başlamıştır. Eski Belediye Sarayı Binasının mimarının Mösyö Mimar Riçi olması yabancı mimarların bu dönemdeki etkisine de işaret etmektedir.

Öz $\quad$ Belediye Binasının plan özelliklerinde belirgin bir üslup değişikliği olmadığı; ancak doğu ve kuzey cephelerinde oryantalizmin mimari öğeleri olan at nalı kemerli pencere ve kapı formlarının, giriş kapısında kullanılan moresk sütun başlıklarının yapı üzerinde üslup açısından değişiklikler meydana getirdiği görülmektedir.

Ayrıca yapının doğu, batı ve kuzey cephelerinde yatay korniş ve dikey plasterlerin birbirlerini keserek yapı yüzeyinde düzenli ve dengeli bölümler oluşturması Neoklasik ve Neorönesans üsluplarının yapı üzerinde meydana getirdiği değişikliğin bir göstergesidir. Eski Belediye Sarayı Binası cephe tasarımında, hem doğu kökenli Oryantalizm hem de antik Yunan ve Roma kökenli Neorönesans ve Neoklasik üslupların bir arada kullanılması yapının Eklektik (seçmeci) anlayışın bir ürünü olduğunun birer belgesi niteliğindedir.

Anahtar Kelimeler Batılılaşma, Eski Belediye Sarayı, Cephe, Eklektik.

\footnotetext{
* Bu makale Atatürk Üniversitesi Sosyal Bilimler Enstitüsü Sanat Tarihi Anabilim Dalı'nda hazırlanan ve 2015 yılında tamamlanan "Samsun' da XIX. Yüzyılda Batı Tesirli Binaların Cephe Mimarisi" başlıklı Yüksek Lisans Tezinden üretilmiştir.

** Gaziosmanpaşa Üniversitesi Zile Meslek Yüksekokulu Mimarlık ve Şehir Planlama Bölümü Mimari Restorasyon Program, Zile/Tokat, e-mail: serpil.seyfi@gmail.com orcid.org/0000-00029902-5309

*** Ordu Üniversitesi Fen-Edebiyat Fakültesi Sanat Tarihi Bölümü, Altınordu/Ordu, e-mail: bayhanahmetali@hotmail.com https:// orcid.org/0000-0003-2496-6136
} 


\title{
Serpil SEYFI-Ahmet Ali BAYHAN
}

\section{A WESTERNISATION SAMPLE IN SAMSUN: THE OLD CITY HALL}

\begin{abstract}
This study evaluates the history, architecture and frontal designs of the Old City Hall of Samsun, a sample of the westernization in Anatolia which began in the XIX. century, and dwells on the dominant style of these frontal designs and how they changed the building.

Public buildings and other edifices set their classical style aside and began to undergo changes in terms of style of the design in line with trade relations, demographic structure of the city, Levanters and activities of the foreign architects in Samsun which is situated in Anatolia and one of the most important coastal towns of Ottoman Empire that ushered in an era of westernization with the reform of Tanzimat.

Abstract It is seen that there are not any clear-cut style changes in the plan features of the City Hall; however, it can also be seen that window and door forms on the east and the north fronts with horseshoe-shaped cinctures, which are the elements of oriental architecture, and moresque column headings, which are used in the entrance door, provided the building with some changes in terms of style.

Furthermore, on the east, west and north fronts, the fact that horizontal cornices and vertical plasters create orderly and balanced sections by crossing each other on the building surface demonstrates the changes provided by Neoclassical and Neorenaissance styles on the building. The fact that both east-oriented Orientalism and ancient Greece and Rome-oriented Neorenaissance and Neoclassical styles are used together in the frontal design of the Old City Hall Building proves that the building is a product of an eclectic understanding.
\end{abstract}

Key Words: Westernization, the Old City Hall, Front, Eclectic.

\section{Osmanlı Dönemi Belediyecilik Faaliyetleri}

Osmanlı döneminde belediyecilik faaliyetleri Geleneksel Dönem (1299-1839) ve Batılılaşma ve I. Dünya Savaşı Dönemi (1839-1923) olarak iki başlıkta ele alınmaktadır. Geleneksel dönemde Belediyecilik anlayışında en önemli husus, hizmetlerin yürütülmesinde; yerel örgütlenmelerden olan kadılık müesseselerinin, vakıfların, loncaların ve mahallelerin etkin olarak görev üstlenmesidir. Bu yerel örgütlenmeler mahallenin bekçisinin seçiminden mahallenin sosyal yardım faaliyetlerine kadar her türlü işi yapıyorlardı. (Ulusoy ve Akdemir, 2004:148-149). Osmanlı'da Geleneksel Belediyecilik Dönemimin yeterince sistematik bir yapı gelişmemiştir. Bununda temelinde Selçuklu zamanında yaşanan bazı siyasal sorunlar yatmaktadır. Anadolu Selçuklu Devletinde vilayetler, bir anlamda yerinden yönetimin esasına göre teşkilatlandırılmış ve bu vilayetler tamamen bağımsız olarak yönetilmişlerdir. Ancak zaman içerisinde vilayetlerin merkeze karşı bağımsız birer beylik haline gelmesi, 


\section{Samsun'da Bir Batılılaşma Örneği: Eski Belediye Sarayı}

Selçuklu Devletinin parçalanmasında anahtar rol oynamıştır. Bu perspektiften konu değerlendirildiğinde Osmanlı yerel yönetimden uzak kalarak merkeziyetçi bir siyasal sistem kurgulamıştır (Atasoy, 2009:10-11). Bu yüzden de Türkiye modern belediyecilik anlayışı ile karşılaşması için Tanzimat dönemine kadar beklemek durumunda kalmıştır. Bu dönemde şehrin karar alıcıları ve bürokratlar yerel yönetimde batıdaki gibi özerk bir yapıya geçiş yapmak yerine, modern ve sistematik şehirler kurmaya odaklanmışlardır (Kalabalık, 2005:52). Bu kapsamda; 1857 tarihli nizamname uyarınca İstanbul, 14 belediye dairesine bölündü. Fakat sadece 6. Daire-i Belediye'den bahsedilen nizamnamede diğer dairelerin yavaş yavaş teşkil edileceği belirtiliyordu. "6. Daire-i Belediye"nin adı Fransa'dan ve Paris'teki en başarılı yerel yönetim bölgelerinden, kent merkezindeki "Sixeme Arrondissement" 6. Bölge Belediyesi'nden alınmıştır. Sonrasında 1868 tarihli Dersaadet İdar-i Belediye Nizamnamesi ile diğer dairelerde faaliyete geçirildi. 1864 Vilayet Nizamnamesi taşra belediye teşkilatına ait ilk hükümleri içerir (Lewis, 1996:394-395). Bu dairelerin açılması ile birlikte ilgili hukuki düzenlemelerde artmasına rağmen Altıncı Daire-i belediye merkezi hükümetin bir şubesi olmaktan öteye gidememiştir (Ortaylı, 1990: 64). Osmanlı'da taşra teşkilatında ki belediyecilik uygulamaları da 1860'lı yılların sonunda başlamıştır. 1864 yılında yürürlüğe konulan Vilayet Nizamnamesine göre her köy bir "daire-i belediye" sayılmıştır. Bunun dişında şehir ve kasabalara belediye kurulmasına yönelik bir hüküm bulunmamaktadır (Tümerkan, 1946:37).

Osmanlı döneminde ki belediye binalarını mimari açıdan batığımızda; Altıncı Daire-i Belediye'nin toplumun ihtiyaç duyduğu sosyolojik, siyasal ve ekonomik ihtiyaçları göz önünde bulunduran bir mimari ile yapıldığı görülmektedir. Altıncı Daire-i Belediye, Şişhane meydanında Meşrutiyet ve Yolcuzade İskender Caddelerinin kesiştiği noktada yer alır. Eduard Blacque Bey'in ilk başkanlığı döneminde (1879-1883), İstanbul' da başka eserlerde de imzası olan mimar Giovanni Barborini tarafından inşaa edilmiştir. Dik eğimli bir arazide yer alan yapı, Şişhane meydanından merdivenlerle çıkılan yüksek bir platform üzerine yapılmıştır. Bina önemli işleviyle bulunduğu semte de adını vermiş ve Meşrutiyet Caddesi' nin başlangıcı "Daire" olarak isimlendirilmiştir. Bina simetrik cephesi, geniş kat silmeleri, saçak silmeleri, köşe plastları, pencere korkuluk ve alınlarıyla dönemin Fransız etkisiyle yapılmış Beyoğlu mimari eserlerinin bir parçasıdır (Toprak, 1994). Yine aynı dönemde taşrada yapılan belediye binalarından önemli üsluba sahip olanlardan biride Bursa Belediye binasıdır. 1867 yılında kurulan Bursa Belediyesi'nin binası, 1880'de Ahmed Vefik Paşa'nın Vali, Hüseyin Hüsnü Efendi'nin Belediye Başkanı olduğu dönemde inşa edilmiştir. Bina yapım tekniği ve dış cephe özellikleri bakımından, 18. y.y. dan itibaren Osmanlı

| Gaziosmanpaşa Üniversitesi Sosyal Bilimler Araştırmaları Dergisi 


\section{Serpil SEYFI-Ahmet Ali BAYHAN}

mimarisinde görülmeye başlayan Batılılaşma eğilimlerini yansıtmaktadır. Osmanlının farklı dönemlerine ait özelliklerini bir arada görebileceğimiz Bursa Belediye Binası, Nafia Nazırı İbrahim Edhem Paşa tarafından 1873 Viyana Uluslararası Sergisi için hazırlatılan "Usul-i Mimar-i Osmani" adlı yapitta savunulan "Neo Osmanlı" kuramını sergileyen bir bina olarak karşımıza çıkmaktadır (Bursa Kültür Varlıkları Envanteri: Anıtsal Eserler, Bursa Büyükşehir Belediyesi Yayınları,269). Ayrıca Bursa da sosyolojik ve coğrafi anlamda önemli bir konuma sahip olan İnegöl'de belediye örgütü Hüdavendigar Vilayeti Salnamesine göre 1870'li yıllarda inşa edilmiştir. Kurulduğu yıllarda öncelikle çarşı içinde ki bir binada hizmet veren belediye daha sonra 1884 yılında tek katlı bir binaya nakledilmiştir. Bu bina ihtiyaca cevap veremediği için 1924'te otel olarak kullanılan bir binaya taşınmıştır ve bu binada 1992 yılına kadar hizmet vermiştir. Bu bina otel olarak planladığ1 için oldukça ilginç bir mimariye sahiptir. Üç katlı açık bir orta avlu etrafında gelişen bir yapıdır. Binanın plan kurgusu Osmanlı son dönem iç avlulu şehir hanlarına benzemektedir. Belediye hizmetlerini tam olarak karşılamak için farklı zamanlarda binaya ek ilaveler yapılmıştır. (Yazıcı, 2010:20-23). Anadolu'daki bir diğer önemli belediye binası da Sivas Belediye binasıdır. Geç dönem Osmanlı kamu yapılarında karşılaştığımız mimari formların dışına çıkmayan Sivas Belediye binasının yapımına 1913 yılında başlanmış ve I. Dünya savaşı ile Kurtuluş savaşından dolayı inşası oldukça uzun sürerek 1923 yılında tamamlanmıştır. Sivas Belediye binası kareye yakın bir plana sahip, bodrum, zemin ve zemin üstünde bir kattan meydana gelmektedir. Doğu-batı eksenine yerleştirilmiş, katlar arasında geçişi sağlayan çift kollu merdivene sahip koridor ve koridor çevresine yerleştirilen odalardan meydana gelen plan şeması ile dönemin kamu eserleri arasında belirgin bir farkı bulunmamaktadır. Dört cephesinde de dışa açıklığı sağlayan pencerelere sahip olan yapıya doğu (ön cephe) ve batı cephelerinde bulunan birer kap1 ile giriş yapılmaktadır. Dört cephesini dolanan saçağı, yatay olarak tüm cepheleri iki bölüme ayıran silme hattı, teğet kemerli pencereleri, dışa taşkın giriş bölümünde yer alan ve Selçuklu-Osmanlı taş süsleme sanatına gönderme yapan süsleme detayları ile eser, dönemin adıyla "Milli Mimari Rönesansı" üslubuna uygun olarak tasarlanmış, dönemin mimari eğilimine uyum göstermiştir (Kolay, 2016:489). Trabzon'da ise tam olarak bir belediye binası olmamakla breaber diğer kamu binaları belediye hizmeti için kullanılmıştır. Trabzon'daki meydan alanı, kentin doğu yönünde, yaklaşık aynı doğrultuda bulunan Belediye Meydanı olmuştur (Yazıc1, 2008:949). Sonuç olarak “ Tanzimattan Cumhuriyet'e uzanan süreçte önemli bir yer tutan yerel yönetimler ile bu yerel yönetimlerin belediye dairesi olarak tanımlanan binaları dönemin önemli kamu yapılarıdır. 


\section{Samsun'da Bir Batılılaşma Örneği: Eski Belediye Sarayı}

Belediye binalar yerleşim bölgesinin merkezinde meydan düzenlemesinin ana elemanlarından biridir. Bu binalar dönemim sivil mimarlı/ konut örnekleri ile benzer özellikler taşımaktadır. Bağımsız olarak inşa edilen belediye binaları olduğu gibi, bazı konutlarında bu amaçla işlevdirildiği anlaşılmaktadır." (Yazıcı, 2010:23)

\section{Samsun'un Önemi ve Eski Belediye Sarayı'nın Tarihçesi}

Samsun sahip olduğu coğrafi konumu ile ilk çağlardan itibaren Karadeniz bölgesinde önemli bir liman şehri olarak görülmektedir. Birçok farklı medeniyet gibi, Atinanılar da Amisos adını verdikleri ilk ticaret kolonisini M.Ö. 5. yüzyılın ortalarında Samsun'da kurmuşlardır. İç bölgelerle ulaşımının kolay olması, Basra, Bağdat, Urfa, Diyarbakır ve diğer şehirlere uzanan ticaret yolunun denize açılan kapısı konumunda bulunması Samsun'un önemini arttırmıştı (Tellioğlu, 2011:27-35). Bu bakımdan Samsun'un gelişimi, Trabzon'un aksine dış ticaretten değil, 19. yüzyılın ikinci yarısında Osmanlı tarımsal üretiminde görülen artışa paralel olarak gerçekleşen iç kaynaklardan ortaya çıkmıştı (Baskıcı, 2005:86-87). 19. Yüzyılın sonlarında Buharlı gemilerin ticaret yollarında yeni alternatifler yaratmak için başladıkları Karadeniz seferleri ile de Samsun hem iç hem de dış Pazar için önemli bir liman kentine dönüşmüş ve şehirde büyükelçilikler açılmaya başlamıştır. Diğer taraftan Samsun'un çok uluslu nüfus yapısı göz önüne alındığında her geçen gün büyümesi doğal bir sürece dönüşmüş̧tür. Çok uluslu ticari faaliyetler yürütmek ve farklı uluslardan gelen insanlara hizmet vermek için Samsun'da Belediye çalışmaları daha önemli bir konuma kavuşmuştur (Yılmaz, 2014:58-65). Samsun sahip olduğu coğrafi konumu ile ilk çağlardan itibaren Karadeniz bölgesinde önemli bir liman şehri olarak görülmektedir. Birçok farklı medeniyet gibi, Atinanılar da Amisos adını verdikleri ilk ticaret kolonisinin yanında M.Ö. 5. yüzyılın ortalarında Samsun'da kurmuşlardır. İç bölgelerle ulaşımının kolay olması, Basra, Bağdat, Urfa, Diyarbakır ve diğer şehirlere uzanan ticaret yolunun denize açılan kapısı konumunda bulunması Samsun'un önemini arttırmıştı (Tellioğlu, 2011:27-35). Bu bakımdan Samsun'un gelişimi, Trabzon'un aksine dış ticaretten değil, 19. yüzyılın ikinci yarısında Osmanlı tarımsal üretiminde görülen artışa paralel olarak gerçekleşen iç kaynaklardan ortaya çıkmıştı (Baskıc1, 2005:86-87). 19. Yüzyılın sonlarında Buharlı gemilerin ticaret yollarında yeni alternatifler yaratmak için başladıkları Karadeniz seferleri ile de Samsun hem iç hem de dış Pazar için önemli bir liman kentine dönüşmüş ve şehirde yabancı büyükelçilikler açılmaya başlamıştır. Diğer taraftan Samsun'un çok uluslu nüfus yapısı göz önüne alındığında her geçen gün büyümesi doğal bir sürece dönüşmüştür. Çok uluslu ticari faaliyetler yürütmek ve farklı uluslardan gelen insanlara hizmet vermek

| Gaziosmanpaşa Üniversitesi Sosyal Bilimler Araştırmaları Dergisi 


\section{Serpil SEYFI-Ahmet Ali BAYHAN}

için Samsun'da Belediye hizmetleri daha önemli bir konuma kavuşmuştur (Yılmaz, 2014:58-65). Bu kapsamda modern bir belediye binasına ihtiyaç doğmuştur.

Samsun'un Pazar Mahallesi, Necip Bey Caddesi'nde bulunmakta olan Eski Belediye Sarayı, Gabilizade Necip Bey tarafından 1913-1915 yıllarında inşa ettirilmiştir. Mimarı İtalyan Mimar Mühendis Mösyö Riçídir (Sarısakal, 2002: 285); ancak Riçi ismine başka bir kaynakta rastlanılmamaktadır. Osmanlı arşivlerinde Dosya No 1834, Gömlek No 54 olan belgede yeni inşa edilen Samsun Hükümet Konağı'nın inşaat masrafları ve tesviyesi ile ilgili bilgiler mevcuttur; fakat belgede böyle bir isimden bahsedilmemektedir. Kütüphanelerde yapılan kaynak taramalarında da bu isme rastlanılmamıştır. Riçi isminin doğru bir yazım şekliyle günümüze gelmemiş olabileceği veya Sarısakal'ın yazım yanlışı yapmış olacağı ihtimaller dâhilindedir. Ayrıca sadece Mösyö Riçi şeklinde tabir edilen kişinin bir soyadının da belirtilmemesi bu şahısla ilgili bilgilere ulaşmamızı zorlaştırmıştır. Eski Belediye Binası üzerindeki üslupsal değerlendirmeler yapının yine yabancı bir mimar tarafından inşa edilmiş olabileceği fikrinden bizi uzaklaştırmamaktadır.

Yapının balkon korkulukları üzerinde Osmanlı arması kullanılmıştır. Armanın altında iki satır Osmanlıca kitabe bulunmaktadır.

Irrq

ו ו

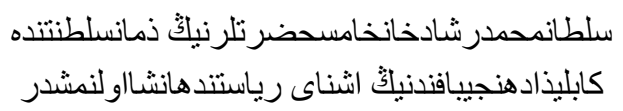

Bu kitabede "1329-1331 Sultan MehmedReşad Han Hamis Hazretlerinin Zaman-ı Saltanatında KabilizadeNecib Efendinin esnai Riyasetinde inşa olunmuşdur."ibaresi yazılıdır. Günümüzde Samsun Büyükşehir Belediyesi Başkanlık binası olarak kullanılmaktadır (Duymaz, 2006: 458 Kitabenin tekrar okunması Nevşehir Üniversitesi Tarih Bölümü Araştırma Görevlisi Emine Mutlu'nun yardımlarıyla yapılmıştır).

\section{Plan Özellikleri}

Yapı, doğu-batı doğrultusunda 26.20 x $24.75 \mathrm{~m}$. kuzey-güney istikametinde 15.80 x $16.05 \mathrm{~m}$. boyutlara sahip kareye yakın dikdörtgen formda olup; kırma çatıyla örtülüdür (Çizim 1). (Yapı üzerinde ilgili kurum tarafından ölçü alma işlemine izin verilmediği için Kültür ve Tabiat Varlıklarını Koruma Kurulu arşivindeki ölçülere bağlı kalınmıştır).

Yapı, zemin kat itibariyle iç mekân düzenlemesi bakımından girişten sonra dikdörtgen bir hol ve onun etrafında doğu-batı doğrultusunda uzanan dikdörtgen odalardan müteşekkil bir düzen ihtiva etmektedir. Yapının kuzey-batı ve güney-batı kenarlarındaki odalarının kuzey-güney yönlü yerleştirilmiş olduğu görülür. Bugün 


\section{Samsun'da Bir Batılılaşma Örneği: Eski Belediye Sarayı}

zemin kat odaları, dükkân olarak kullanılmaktadır. Birinci kat ise; doğu-batı ve güney doğrultuda 'L' şeklinde uzanan bir hol (günümüzde burası bekleme mekânı olarak faaliyet göstermektedir) ile bu holün sağında büyük bir toplantı salonu sol tarafında da dört adet küçük oda şeklinde bir düzen sergilemektedir (Çizim 1). Üst kata geçişler, batı tarafta güney-batı yöndeki oda ile hol arasındaki merdivenlerden sağlanmaktadır. İkinci katta ise kuzey-doğu yönde başkanlık makamı, onun gerisinde dinlenme salonu bulunurken, orta eksende kuzey-güney doğrultusunda ovalleştirilerek genişletilen bir hol ile sol tarafta da orta eksenin genişletilmesiyle başkanlık makamı gibi asimetrikleşen doğu yönde bir oda ve güney tarafta iki dikdörtgen odaya yer verildiği görülmektedir. Batılılaşma süreci ile Nuruosmaniye Camiindeki yarım daire biçimindeki avlu ve aynı şekilde dışarı taşırılan mihrap nişi (Bakır, 2013, 85) ve daha sonra sivil mimariye sirayet eden Barok tesirle kösseleri pahlandırılarak oval forma ulaşılan orta sofalı Türk evini (Bakır, 2013, 47) akla getirmektedir. Bu durum plan üzerinde az da olsa batı etkisinin varlığının bir kanıtı niteliğindedir.

Yapının doğu ve batı yönlerde bulunan iki adet giriş kapısı bulunmaktadır. Bu girişlerden batı yöndeki giriş kapatılmış (Resim 14) ve batı yönden yeni Belediye binası ile bağlantılı bir tüp geçit oluşturularak yapının orijinal kimliği büyük oranda zedelenmiştir (Çizim1-5) (Resim 10-12).

\section{Cephe Düzeni ve Süsleme Özellikleri}

Bina üç katlı olarak inşa edilmiştir. Kareye yakın dikdörtgen formlu olan binanın cephe tasarımlarında benzer unsurlar kullanılmıştır.

Yapıya giriş doğu yönden sağlanır. Doğu cephede dikey plaster ve yatay kornişlerin üç kat boyunca uzanarak birbirlerini kesmesi neticesinde, cephede bölümler oluşturulmuş ve aksiyal bir görünüm elde edilmiştir. Bu bölümler içerisine her katta ikişer pencere yer alırken; orta eksendeki balkonlu alanlarda ve giriş kısmında birer kapı açıklığı bulunmaktadır.

Cephenin simetrik ve aksiyal yüzeylere bölünmesi Rönesans ve Neoklasik cephe anlayışına işaret etmektedir.

Bu cephede; girişte dört bölüm halinde yerleştirilmiş camekânlı dükkân birimleri bulunur. Birinci katta orta eksende balkon ve onun sağında dört ve solunda dört olmak üzere ikili düzende yerleştirilmiş, toplam sekiz pencereye yer verilmiş ve ikinci katta da aynı yerleşim düzenine sadık kalınarak bir ve ikinci katta toplam iki balkon ve on altı adet pencereye yer verilmiştir.

Doğu cepheyi giriş katından itibaren incelediğimizde; cephenin orta aksına yerleştirilmiş bir ana giriş kapısının mevcut olduğu görülmektedir (Resim 1-7).At nalı kemerli olan bu kapı, önde bağımsız iki kalın, kare ayak ve moresk başlıklı, silindirik

| Gaziosmanpaşa Üniversitesi Sosyal Bilimler Araştırmaları Dergisi 


\section{Serpil SEYFI-Ahmet Ali BAYHAN}

gövdeli iki sütunla birlikte dikdörtgen bir şema oluşturmaktadır. Söz konusu portal; dışarıya doğru taşıntı yaparken (Resim 7-8), kapı yönünde yapıyla kaynaşmış kare sütunlarla portal tamamlanmaktadır (Resim 9). Binanın taç kapısını oluşturan kemerler öne düz, yanlara at nalı olarak açılmaktadır. Burada at nalı kemer ve moresk sütun başlı̆̆ının kullanımı oryantalist bir tasarım anlayışının yapıya hâkim olduğunun göstergesidir. Kapıyı şekli boyunca çevreleyen bir bordür bulunmaktadır. Kapının yuvarlak kısmını çevreleyen dikdörtgen şekilli silmeler birbirine bağlanarak kapının iki tarafından aşağıya kadar uzanmaktadır. Kapı kemerini sarmalayan, kare panoların birleşimiyle meydana gelen dikdörtgen çerçeve, üzengi taşına kadar devam etmektedir. Kapının önündeki kare ayaklar üzerinde alt kısımdan itibaren süslemelere yer verilmiştir (Resim 9). Kare sütunun üst kısmındaki bordür içinde kenger dal ve yapraklarından oluşan girift bir bitkisel kompozisyon bulunmaktadır. Buradaki bordürün altını destekleyen bir bileziğe yer verilmiştir. Sütunun üstünde yine aynı düzenlemeye sahip bir bordür ve bunun içinde ise yukarı bakan kenger yaprağı motifleri ve aralarında daha küçük, beş yapraklı kengerler bulunmaktadır. Bunlar sırayla bir büyük bir küçük çiçek şeklinde yerleştirilmiştir.

Lale Devri eserlerinde süsleme anlayışı da değişmeye başlamıştır. Mimari süslemelerde; kartuşlar, $C$ ve $S$ kıvrımları ve akant yapraklarının kullanımı yaygınlaşmıştır (Eyice, 1978-1980:165). Kenger motifinin bu yapıda tercih edilmesi yine batılı üslupların etkisi olarak değerlendirilebilir. Bu çiçeklerin uzantısında sütunun yüzeyinde dikdörtgen çerçeve içinde küçük geometrik bir pano bulunur. Bu panonun devamında kırık hatlı "Z" şeklinde yukarı doğru daralan bir motif ve onun en üst kısmında at nalı şeklinde bir (Resim 8) düzenlemeyle mağrip etkili bir tasarım elde edilmiştir.

Sütunun yukarısında, dört sıra boyunca kabartma şeklinde düz dört şerit şeklinde bir düzenlemeye ve iki sıra taş silmeye yer verilmiştir. Devamında sütun başlığının alt kısmında iki sıra halinde uzanan plastik etkili bir şerit üzerinde, dış bükey bir düzenleme söz konusudur. Bunu yatay şeritler takip eder. Bu motifin devaminda yüzeyden diş bükey ve dikey olarak uzanan lotuslara yer verilmiştir.

Kapının sağ tarafında iki ve sol tarafında iki olmak üzere toplam dört dükkân bulunmaktadır. Dükkânları birbirinden dikey hatlı uzanan plasterler ayırmaktadır. Bu plasterler üzerinde de süslemelere yer verilmiştir. Plasterler alttan itibaren bir kaide görevi yapan kısmının kare olduğu ve gövde kısmının ortasında kaplama şeklinde beş adet, kare taş süslemenin var olduğu görülmektedir. Bu taş kaplamın iki tarafında birer adet sütunceye yer verilmiştir. Bu süslemenin üst kısmına bir pano yerleştirilmiş 


\section{Samsun'da Bir Batılılaşma Örneği: Eski Belediye Sarayı}

ve içerisinde dört yönlü uzanan kenger dal ve yapraklarından oluşan bitkisel kompozisyon oluşturulmuştur (Yaban enginarı yaprağı biçiminde bir bezeme örgesi. İlk kez Antik Yunan Sanatı'nda kullanılmış, Avrupa'da XIX. yüzyılın sonuna kadar uygulanması sürmüştür. Özellikle korint sütun başlıkları üzerinde görülür) (Tanyeli, Sözen, 2012:18). Bu kompozisyonun devaminda yine dikey lotuslardan oluşan bir süsleme bulunmaktadır (Resim 7).

Yapının giriş kısmını oluşturan kare sütunlar birinci kattaki balkonu taşımaktadır. Korkuluklarda iki sıra halinde geometrik taş bir dekorasyon dizisi mevcuttur. Bu dizi arasındaki bölümlerde küçük üçgen motifleri ile plastik bir görünüm elde edilmiştir. Alttaki sütunların üzerine denk gelen korkulukların köşe kısmında sütun başlığ1 görünümü oluşturulmuştur. Bu sütun başlığ1 görünümündeki dikdörtgen köşe korkuluğu üzerinde; panoda yuvarlak kemer içine yerleştirilmiş üç dilimli kemer motifi yer almaktadır (Resim 1-4).

Giriş katla birinci katı yatay saçakta da palmet dizisinden oluşan bir kompozisyon birbirinden ayırmaktadır (Resim 5).

Birinci katın orta ekseninde balkon bulunurken; pencerelerin dördü balkonun sağında, dördü de solunda olacak şekilde teşkilatlandırılmıştır. Pencereler, at nalı kemerlidir ve pencerenin üst kısmından itibaren alınlıklarını kuşatacak şekilde üzengi taşına kadar uzanan dikdörtgen bir çerçeve pencereyi sarmalamaktadır. Pencerelerde iki renkli taş kullanımı dikkat çekicidir. Pencerenin plasterler kısımları sütunce formunda ve düz başlıklı olarak yapılmıştır. Pencere denizliklerinin alt kısımları da, yarım yuvarlak ve istiridye şeklindedir. Bu dilimli bezeme Doğu mimarisine ait bir unsurdur. Bu kattaki balkon kapısının, basık kemerli kısmında aşağıya bakan ters palmet dizisi bulunur (Bir sapın iki tarafından simetrik olarak sıralanmış uzunca yapraklardan oluşan üsluplaştırılmış bitkisel bezeme öğesi. En eski Mezopotamya uygarlıklarından başlayarak tüm çağlarda ve üsluplarda görülür) (Sözen, Tanyeli, 2012:18). Bu katta üst kat balkonu taşıyan kırık hatlı volütlere yer verilmiştir. Ayrıca bu kattaki plasterler üzerindeki kare panolar içerisinde palmiye dal ve yapraklarından oluşan bitkisel süslemeli kompozisyonlar bulunmaktadır (Resim 6).

İkinci katı birinci kattan ayıran bordürde damla motifli süsleme kuşağı cephe boyunca uzanmaktadır.

İkinci katta da pencere ve uygulaması dikkat çekicidir. İkinci katla birinci kattaki pencere uygulamalarının birbirinden farklı şekilde olması cephede hareketlilik sağlayan unsurlardandır. Bu katta dikey uzanan plasterlerin üzerinde yer alan panolarda ise; geniş yapraklı kenger yapraklarının ve dallarının dört yönlü uzandığı ve uzanan dalların birleşerek dairesel motifler oluşturduğu bitkisel dekor bulunmaktadır.

| Gaziosmanpaşa Üniversitesi Sosyal Bilimler Araştırmaları Dergisi 


\section{Serpil SEYFI-Ahmet Ali BAYHAN}

Burada balkon yine orta aks boyunca devam eder. Bu kattaki balkon korkulukları ve düzenlemesi ikinci katın balkonundan farklı yapılmıştır. Balkon önde ikisi bağımsız kare, ikisi yapıyla bütünleşmiş dört sütunla oluşturulmuştur. Balkon dört sütunun desteklediği üç sivri kemerli olarak ön cepheye ve birer sivri kemerle de yanlara açılmaktadır. Bu kemerlerden ortadaki sivri kemerin kilit noktası düğüm Düğüm motifi; şeklindedir (Resim 2-4). Hitit, Mısır sanatı da dâhil olmak üzere Yunan, Roma, Sasani, Bizans gibi Akdeniz uygarlıklarında ayrıca İslam sanatında da kullanıldığını görmekteyiz. Emevi ve Endülüs Emevi, Abbasi devrinde de kullanılmaya devam etmiştir. Türk İslam öncesi dönemlerde de sanat eserlerinde karşılaşılmıştır. (Alev Çakmakoğlu Kuru, Orta Çağ Anadolu Türk Mimarisinde Düğüm Motifi ve İkonografisi, Erdem Atatürk Kültür Merkezi Dergisi, S.51, 2008, 2425. ) Yandaki sivri kemerlerin üst kısminda yuvarlak çerçeve içinde ortada bir üçgenden gelişen geometrik bir motif, bu motifin etrafını çevreleyen birbirine geçmeli geometrik bir zincir dekorasyonu bulunmaktadır. Kare sütunların başlığının alt kısmında palmet ve rumilerin girift bir kompozisyon oluşturduğu bir bordür vardır. Buradan yukarı doğru kademeli bir daralma söz konusudur. Sütunun üst kısmında başlık gibi duran bir pano ve devamında geometrik geçmeli zincir motifli bir pano yer almaktadır. Önde silindirik gövdeli iki granit sütun ortadaki sivri kemerleri taşımaktadır. Bu iki sütun düz başlıklı yapılmış, sütunların aşağı kısmı bombeli, kaidesi da kare şeklindedir. Onların uzantısında bulunan korkuluklardaki dikdörtgen panoda yaprak motifine yer verilmiştir. Bu panonun iki yanındaki alanlarda ise; birbirine geçmeli motiflerle üçgen motifi oluşturulmuştur. Kalın sütunların alt kısmına gelen panoda da geometrik bir motif ve kıvrık dallı bitkisel bir süsleme yer almaktadır. Yaprak motiflerinin arasında kalan kısımda yapının kitabesine ve kitabe üzerinde Osmanlı armasına yer verildiği görülmektedir (Resim 3-4).

Balkon kemerlerinin üst kısminda, bir kuşak ve bu kuşakta birbirine geçmeli zincir şeklinde bir düzenleme söz konusudur. Daha yukarıda küçük şerit bordürde iç bükey mukarnas yuvalarını hatırlatan ya da üçlü kemer şeklinde bir kuşak uzanır. Onun devamındaki bordürde de önceki kuşaktaki bu şeklin geniş hali görülmektedir. Yapının üst kısmında dendanlara yer verilmiş ve bu dendanlar batı ve kuzey cepheleri de taçlandırmaktadır. Çatı kısmındaki dendanlarda yapının kalevâri bir görüntüye sahip olmasına neden olmuştur.

İkinci kattaki pencere düzenleri de simetrik olup, dikdörtgen ve basık kemerli forma sahiptirler. Pencerelerin denizlik kısımları yalın ancak alt kısımlarında yaprak motiflerine yer verilmiş, ayrıca yanlara uzanan uç kısımları üçgen motifi ile tezyin 


\section{Samsun'da Bir Batılılaşma Örneği: Eski Belediye Sarayı}

edilmiştir. Denizliğin aşağıya uzanan uç kısımlarında ise; üzerinde dikey çizgiler olan kare ve devamında daire şeklinde sonlanan bir süsleme ile karşılaşılır. Buradaki pencerelerin kilit taşında da, kemer sorgucuna yer verilmiştir. Bu sorguçlar Neobarok etkilerin varlığına işaret etmektedir. Pencerelerin alınlıklarını çevreleyen çatı formunda başlayıp pencere kemerlerinin üzengi taşına kadar inen sarmal plasterler, pencere çevresinde bir ahenk oluşturmaktadır.

Çatı saçağının altında mukarnas yuvaları ve palmetlerin birleşmesi ile oluşan dekoratif yatay bordür kuşağı uzanır. Burada dikkat çekici unsurlardan birisi de yapıyı dikey olarak bölen plasterlerin çatı kısmında bulunan kavuk şeklindeki öğelerle birleşmesidir. Balkon sütunlarının devamında aynı uygulamaya yer verilmiştir. (Çizim 2-5). Bu plasterlerin üzerinde kenger motiflerinin dört yönlü uzandığ1 ve dallarının birbirine bağlanarak dört yönlü dairesel motifler oluşturduğu süsleme pano içerisine yerleştirilmiştir.

Yapının batı cephesi yeni belediye binasıyla bağlanan bir geçitle orijinalliğini kaybetmiştir (Resim 10). Bu yönde dört basamakla ulaşılan bir girişin olduğu ve sonradan bu kapının kapatılmış olduğu kalan izlerden anlaşılmaktadır (Resim 14). Burada giriş katta dört küçük ve dört büyük olmak üzere toplamda sekiz pencere bulunurken; birinci katta dört, ikinci katta beş pencere mevcuttur. İkinci kata nazaran birinci kattaki bir pencere eksikliği tüp geçitin burada açılmasıyla ilgili olmalıdır. Ana cepheyle bezer nitelikler taşıyan bu cephe ona nazaran daha sade ele alınmıştır. Cephe dikey ve yatay hatlarla yine hareketlendirilmiş ve üç yatay kuşakla altı dikey kuşakla beş bölümlü hale getirilmiştir. Bu cephede giriş katta pencereler yere kadar uzanmakta olup; dikdörtgen ve basık kemerli pencere formundadır.

$\mathrm{Bu}$ pencerelerin kilit taşlarında düz bir kemer sorgucu bulunur ve bu pencerelerin alınlık kısımlarında daha küçük basık kemerli pencerelere yer verilmiştir. Alınlık niteliğindeki bu küçük pencerelerin çerçevesi de kendi formunda ama kırık hatlı olarak değerlendirilmiştir. Birinci katta dört adet dikdörtgen, pencere bulunur (Resim 10-11-12).

Birinci katta da ikiz pencere düzenlemesi söz konusudur. Pencereler dikdörtgen formdadır. Pencereleri birleştiren ara plasterin üzerindeki dekoratif amaçlı sütunce formunda dikey bir süsleme meydana getirilmiştir. Pencere denizlikleri çok sade ele alınmıştır. Bu ikili pencerelerin etrafını dış kısımdan itibaren kırık hatlı olarak uzanan, pencerenin orta kısmına kadar inmeden pencereyi üç yönden saran ve uç kısmı oval şekilde sonlanan bir silme kuşatmaktadır (Resim 11-12). Birinci katta orta kısım yeni belediye binasıyla bağlantı yapılmış ve buradaki orijinal görüntü yok olmuştur. Birinci katla ikinci katı birbirinden ayıran yatay kornişte de tek sıra halinde at nalı kemer

| Gaziosmanpaşa Üniversitesi Sosyal Bilimler Araştırmaları Dergisi 


\section{Serpil SEYFI-Ahmet Ali BAYHAN}

formunu da anımsatan bir niş kuşağı uzanır. Dikey bordürle kesiştikleri noktalar yine burada sütun kullanıldığı izlenimini verir. Sütunların alt kısımlarında altıgen süslemeler ve at nalı kemer formunda şekiller yer almaktadır (Resim 16).

Giriş katla birinci katın pencereleri aynı düzende oluşturulmuştur. Farklı olarak orta eksende bir ikiz pencere kullanımı söz konusudur. İkinci katta kornişteki düzenlemede ikili mukarnas yuvaları arasında kalan kısımlarda palmet ve rumilerin kullanıldığı bitkisel bir tezyinat vardır. Ayrıca bu cephenin de süsleme açısından zengin olduğu plasterler üzerinde kalan yarım bitkisel ve geometrik motiflerden anlaşılmaktadır (Çizim 4).

Kuzey cephe; doğu cepheye benzer öğelere sahiptir. Dört dikey bordürle üç bölüme ayrılmış olan cephede her katta yanlarda ikişer, orta da birer pencere ile toplamda beşer pencere bulunmaktadır. Bu cephedeki pencereler doğu cephedeki pencere formlarıyla benzerlik göstermektedir. Giriş katında üç bölümlü bir dükkân bulunmaktadır. Cepheyi bölen plaster ve saçakların kesiştiği noktalarda panolara yer verilmiştir. Giriş katın bitimindeki sütunların üzerinde alttan itibaren kare bir kaide onun üzerinde kare bir pano, devaminda ortada dikdörtgen ve devaminda altı adet kare sütun iki yanında da birer sütunce bulunmaktadır. Bunların yukarısında dikdörtgen pano ve panonun içerisinde dört yönde birer çiçek dallarından oluşan girift bir kompozisyon bulunur. Onun üzerinde de dikey hatlı olarak uzanan lotuslar yer almaktadır. Daha üstte de düz yatay hatlı korniş dolanır. Giriş katla birinci katı palmet motiflerinin oluşturduğu yatay bordür ayırmaktadır. (Resim 15-17).

Birinci kattaki pencereler at nalı kemerlidir ve pencerelerin denizlik bölümlerinin alt kısmı dilimli istiridye şeklinde olup; doğu cephenin birinci katındaki pencere düzeni ile aynı şekilde değerlendirilmiştir. Buradaki plasterler üzerinde de doğu cephedeki pano içerisinde palmiye motifleri ile oluşturulmuş kompozisyon aynı şekilde uygulanmıştır. İkinci kattaki dikey uzanan yüzeyden taşkın plasterlerin alt kısımları aynı zamanda birinci kattaki plasterlerin başlığı görünümündedir. Bu kısım dikdörtgen bir pano olup; içinde kenger yaprağı ve dallarının girift düzenlemesiyle zengin bir görünüm elde edilmiştir. İkinci katta da ana cephedeki pencere düzeni tekrarlanmıştır. Sadece orta eksendeki pencere yuvarlak kemerli ancak yine pencere denizliğinin alt kısmı istiridye dilimli ve bombeli olarak yapılmıştır. 


\section{Samsun'da Bir Batılılaşma Örneği: Eski Belediye Sarayı}

$\mathrm{Bu}$ katın saçağını üç cepheyi dolanan mukarnas yuvaları ve palmetlerin oluşturduğu bordür kuşağı dolanır.

Güney cephede herhangi bir kapı veya pencere açıklığı bulunmamaktadır (Resim 18) (Çizim 3-6). Burada Mustafa Kemal Atatürk'e ait altı satırlık bir yazı bulunur. Atatürk'ün yazısı şöyledir:

Ben Samsun'u ve Samsun halkını gördüğüm zaman memlekete ve millete ait bütün tasavvurlarımın kararlarımın herhalde yerine getirilebilir olduğuna bir defa daha kuvvetle inanmıştım, Samsunluların hal ve durumlarında gördüğüm gözlerinde okuduğum vatanseverlik, fedakârlık, ümit ve tasavvurlarımı müspet bir inanca götürmeye yeter olmuştu...

24 EYLÜL 1924 SAMSUN

\section{Malzeme ve Teknik}

Yapı kesme taş malzemeyle kargir olarak inşa edilmiştir.

\section{Genel Değerlendirme ve Sonuç}

Osmanlı İmparatorluğu'nun XVIII. yüzyıl içerisinde siyasi, ekonomik ve askeri alanlarda güçsüzleşmesi Batıdaki gelişmeleri takip etmek için yönünü batıya çevirmesine neden olmuştur. Bu da Osmanlı İmparatorluğu içerisinde sosyal alanlarda büyük değişimleri de beraberinde getirmiştir.

Osmanlı Başkenti İstanbul'da mimari ve diğer sanat alanlarında başlayan değişim sürecinin diğer kentlerde de kendini göstermesi daha çok XIX. yüzyıl içerisinde gerçekleşmiştir. Bu değişimi gösteren Anadolu'daki örneklerden bir tanesi de Samsun şehridir.

XIX. yüzyıl içerisinde hem konumu, hem de etnik yapısı itibariyle dikkat çeken Samsun şehri İmparatorluğun içinde bulunduğu sosyal, ekonomik ve siyasi ortamdan büyük oranda etkilenmiştir.

$\mathrm{Bu}$ değişimin önemli örneklerinden olan Samsun Eski Belediye Sarayı Binası, Eklektik anlayışın önemli temsilcilerindendir. Cephe tasarımlarında Oryantalist, Neorönesans, Neoklasik ve Neobarok öğelerle zengin bir mimari örnek olmuştur.

Bu yapı dönemin önemli bir yapısı olduğu için üzerine birçok akademik çalışma yapılmıştır. Kolay (2017) tarafından yapılan "Geç Dönem Osmanlı Mimarisinde Oryantalist Üslupta Bir Örnek: Samsun Belediye Binası' isimli çalışmada yapının tarihsel ve belediyecilik alanındaki gelişimlerine vurgu yapılırken; mimari tasarım ve süsleme alanında detaylı bir bilgi verilmemekte ayrıca yapı sadece oryantalizm çerçevesinde değerlendirmektedir. Makale çalışmam 2015 tarihli tez çalışmama dayanmakta olup; 20. Yüzyılda meydana gelen cephe düzenlemeleri ile dikkat çeken ve dönemin algısını yansıtan ve Anadolu'da yaygın görülmeyen süsleme ve tezyinat

| Gaziosmanpaşa Üniversitesi Sosyal Bilimler Araştırmaları Dergisi 


\section{Serpil SEYFI-Ahmet Ali BAYHAN}

anlayışını yansıtan bir yapı örneği olan Belediye Sarayını yayımlama ihtiyacı duymama neden olmuştur. Çalışmamda cephe üzerinde var olan bütün düzenlemeler ve süsleme öğeleri tanımlanarak hangi üslupları işaret ettiği ile ilgili bilgiler verilmiş sadece oryantalizmden öte diğer üslupların varlığı belirlenmiştir. Bu sebepten ötürü bu çalışmam Kolay'ın sadece üslupsal açıdan oryantalizm üzerinde durduğu çalışmasından bu yönüyle ayrılmaktadır. Diğer bir açıdan kendi çalışmam diğer makalede bulunmayan yapıya dair üslupları ortaya koymasıyla diğer çalışmayı tamamlayan bir çalışma olarak da değerlendirilebilir.

Yapı elemanları olan ana kapının önündeki revaklı bölümde bulunan ve birinci kat balkonunu taşıyan sütun başlıklarının oturduğu kırık çizgili kemer formu, Osmanlı mimari anlayışından uzaktır. Ayrıca balkonlarda yer alan kapı dilimli kapı kemerleri, ikinci kat balkonunun üst kısmındaki düğüm motifi ve çatı hizasındaki kırık hatlı çizgilerden oluşan ve yukarı doğru daralan dendan parapetler Oryantalist tesirler olarak değerlendirilebilir (Kolay, 2017,60). Öne ve yukarı taşıntı yapan portal, İstanbul ve Anadolu'da birçok kamu yapısıyla benzerlik göstermektedir. İstanbul Duyun-u Umumiye Binası (İstanbul Lisesi 1897) (Cansever, 2011,103; Gözde Çelik, Zeynep Kuban, 2009:72) Sinop Hükümet Konağ1 (Resim 19.) (Topçubaşı; Eyüpgiller, 2010:114115), Kastamonu Hükümet Konă̆1 (1901) ((Topçubaşı; Eyüpgiller, ,2010:110-111), Sivas Kongre Binası (Kuzucu, 2006,112), Amasya Belediye Binası (1913-1923) (Resim 20) (Kolay, 2016:491) ile benzerlik göstermektedir. Söz konusu yapılarda 2 veya 3 katlılık mevcut olup, giriş bölümünü oluşturan portalın ehemmiyetle vurgulandığı aynı zamanda balkonlu veya balkonsuz olan örnekleri ile Osmanlı ekletisizmini yansıtan önemli yapılar olduğu dikkat çekmektedir.

Yapıyı, Samsun kamu binaları olan Samsun Bölge İdare Mahkemesi Binası (Eski Hükümet Konağı) (Resim 23), Samsun Garanti Bankası (Eski Osmanlı Bankası) (Resim 24), Ziraat Bankası (Eski Emniyet Sandığı), Ruh ve Sinir Hastalıkları Binası (Canik Hamidiye Hastanesi) (Resim 28), Yol-İş Sendikası (Eski Fransa Konsolosluğu) (Resim 25), İlkadım Kültür Sanat Eğitim ve Kültür Müdürlüğü Binası (Resim 26), Gazi Müzesi (Mantıka Palas) (Resim 27) ile birlikte değerlendirdiğimizde; 19. yüzyılın sonu 20. Yüzyılın başlarına tarihlendirilen bu yapılardan cephesel düzenlemelerindeki oryantalist tasarımı ile ayrılırken; seçmeci anlayışı ile fark yaratmaktadır (Seyfi, 2015:104).

Yapıda at nalı ve renkli taş ile işlenen kemer biçimine ve moresk sütun başlıklarının kullanımına rastlamamamız da üslupsal değişikliğin işareti olarak yapıyı aynı dönem inşa edilen yapılarından ayırmaktadır. 


\section{Samsun'da Bir Batılılaşma Örneği: Eski Belediye Sarayı}

Eski belediye Sarayı Binası cephelerinde, doğu-batı sentezli öğelerin bir arada olması nedeniyle yapı, İstanbul Sirkeci Gar Binası (Yavuz, 2008:196) (Resim 21) ile benzerlik göstermektedir (Resim 23).

Eski Belediye Sarayı Binasının pencereleri Oryantalizmin mimari elemanı olan at nalı kemer formunda inşa edilmiştir. Benzer uygulamalar Tokat Köşkü'nün kapıları ve hükümdar locası açıklıkları (1875), Yıldız Sarayı Ortaköy (1789-1807) kapısı kemeri, Fuat Paşa Türbesi (1868) kapı ve pencereleri (Saner, 1998:42), ile Harbiye Nezaretinin bazı pencereleri ile Harbiye Nezareti Köşklerinin pencereleri ve kapısında (Günergun, Kadığlu, 2006:144-145) ve Hamidiye Camisi (1885-1886) ana ibadet mekânında çatıyı destekleyen ahşap sütunların kemerlerinde (Barillari, Godoli, 1900, 38-39) kullanılmıştır.

Yapıda at nalı ve renkli taş ile işlenen kemer biçimine ve moresk sütun başlıklarının kullanımına rastlamamamız da üslupsal değişikliğin işareti olarak yapıyı aynı dönem inşa edilen yapılarından ayırmaktadır. Elhamra Sarayı'nda benzerleri saptanan bu tür başlıklar, bitkisel bezemeli ve mukarnaslı olarak iki ana tipe ayrılır. Fuat Paşa Türbesi (Resim 26), Büyükada Sinagogu (Saner, 1998, 32), Bahriye Nezareti (Çelik, 2009:72), (Resim 22) ve Şale Köşkü-Ziyafet Salonu'nda (Barillari, Godoli, 1900, 40), ayrıca Beylerbeyi Sarayı-Mavi Salon'da (Dündar, 2008: 455) bu uygulamalar görülmektedir.

Samsun'daki bu örnek yapı; Batı tesirlerinin, İstanbul dışında Anadolu'daki etkilerini göstermesi bakımından önem taşımakta ve cephe düzenlemesi ve süsleme özellikleri ile dönemin mimarlık algısını yansıtarak Batılılaşma anlayışında yeni tasarımları arayan nitelikleri ortaya koymaktadır.

\section{KAYNAKÇA:}

Atasoy Veysel, Türkiye'de Mahalli İdarelerin Yapısı ve Yeniden Düzenlenmesi, Türk Dünyası Araştırmaları Vakfı, İstanbul, 1992.

Betül Bakır, Mimaride Rönesans ve Barok Osmanlı Başkenti İstanbul'da Etkileri, Nobel Yayınları, Ankara,2013.

Barillari, Diana \& Gadoli, Ezia, İstanbul 1900 Art Nouveau Mimarisi ve İç Mekanları, YEM Yayınları, İstanbul, 1997.

Çakmakoğlu Kuru, Alev, “Orta Çağ Anadolu Türk Mimarisinde Düğüm Motifi ve İkonografisi”, Erdem Atatürk Kültür Merkezi Dergisi, S.51, 2008, 23-52.

Çelik, Gözde, Kuban, Zeynep İstanbul Tarihi Yarımadası'nda Tanzimat Dönemi İdari Yapıları, İTÜ Fen Bilimleri Enstitüsü, Mimarlık Tarihi Programı, İ.T.Ü Dergisi, S.1.C.8. İstanbul, Mart 2009, 67-80

| Gaziosmanpaşa Üniversitesi Sosyal Bilimler Araştırmaları Dergisi 


\section{Serpil SEYFI-Ahmet Ali BAYHAN}

Duymaz, A. Şevki, “XIX. Yüzyılda Samsun'un Kentsel Gelişimine Dair Birkaç Mimari Örnek”, Geçmişten Geleceğe Samsun, 1. Kitap, Samsun 2006, 449-462.

Dündar, Mesut, Beylerbeyi Sarayı, (Yayımlanmamış Doktora Tezi), Ankara Üniversitesi, Ankara 2008.

Eyice, Semavi, “XVll1. Y.Y’da Türk Sanatı ve Türk Mimarisinde Avrupa Neo-Klasik Üslubu", Sanat Tarihi Yillı̆̆ı, Sayı: IX-X, 1978-80.

Günergun, Feza Sevtap Kadığlu,“İstanbul Üniversitesi'nin Yerleşim Tarihi Üzerine Notlar", Osmanlı Bilimi Araştırmalar, VIII/1,2006, s.136-163

Kalabalık, Halil, Avrupa Birliği Ülkeleri ile Karşılaştırmalı Yerel Yönetim Hukuku, Seçkin Yayıncilık, Ankara.2005

Kolay Emre, Amasya'da Geç Dönem Osmanlı ve Erken Cumhuriyet Dönemi Kamu Yapıları Hakkında Genel Bir Değerlendirme, The Journal of Academic Social Sciences, S.29, 2016, 482-502.

Kolay Emre, "Geç Dönem Osmanlı Mimarisinde Oryantalist Üslupta Bir Örnek: Samsun Belediye Binası", Osmanlı Mirası Araştırmaları Dergisi, S. 9, 2017, 57-68.

Kuzucu Kemalettin, Osmanlı'dan Cumhuriyete Şehircilik, Mimari, ve Eğitim Anlayışındaki Değişmeler Bağlamında Sivas Kongresi Binasının Tarihçesi, Ankara Üniversitesi, Türk Inkilap Tarihi Enstitüsü Atatürk Yolu Dergisi, S.37-38, Mayıs-Kasım 2006, 103-125.

Lewis, Bernard, Modern Türkiye'nin Doğuşu, (Çev: Prof.Dr. Metin Kıratlı), TTK Yayınları. Ankara. 1996.

Saner, Turgut, 19. İstanbul Mimarlı̆̆ında Oryantalizm, Pera Yayıncılık, İstanbul 1998.

Sarısakal, Baki, Bir Kentin Tarihi Samsun, Birinci Kitap, Samsun Valiliği, Samsun 2002.

Seyfi Serpil, Samsun'da XIX. Yüzyılda Batı Tesirli Binaların Cephe Mimarisi, Atatürk Üniversitesi Sosyal Bilimler Enstitüsü Yayımlanmamış Yüksek Lisans Tezi, 2015.

Sözen, Metin, Tanyeli, Uğur, Sanat Kavram ve Terimleri Sözlüğ̈̈, Remzi Kitabevi, İstanbul 2012.

Tellioğlu, İbrahim, Osmanlı Hâkimiyetine Kadar Canik, İlkçağdan Cumhuriyete Canik, Ed: Cevdet Yılmaz, İlkadım Belediyesi Kültür ve Sanat Yayınları: Samsun 2011.

Topçubaşı Mine, K.Kutgün Eyüpgiller, 19. Yüzyılda Kastamonu Eyaleti'nde Hükümet Daireleri, , İtü Dergisi, S.2, 2010, 108-120.

Toprak, Zafer. Altıncı daire-i belediye, Dünden Bugüne İstanbul Ansiklopedisi, 1, Kültür Bakanlığı ve Tarih Vakfı Ortak Yayını, 220-223, İstanbul.1994 


\section{Samsun'da Bir Batılılaşma Örneği: Eski Belediye Sarayı}

Tümerkan Sıddık, Türkiye'de Belediyeler, Tarihi Gelişim ve Bugünkü Durumu, Yaylacık Matbaası:İstanbul.1946

Ulusoy, Ahmet ve Tekin Akdemir, Mahalli İdareler Maliyesi, Seçkin Yayınları, Ankara.2004

Yavuz, Mehmet, "August Carl Friedrich Jasmund ve Mimari Faaliyetleri", Güzel Sanatlar Enstitüsü Dergisi, (21), 2008, 187-209.

Yılmaz, Özgür. Samsun'da Fransız Konsolosluğu'nun Kurulması ve Fransız Arşiv Belgelerine Göre Şehrin Durumu (1840-1870), Karadeniz İncelemeleri Dergisi, 16(16). 2014, 57-86

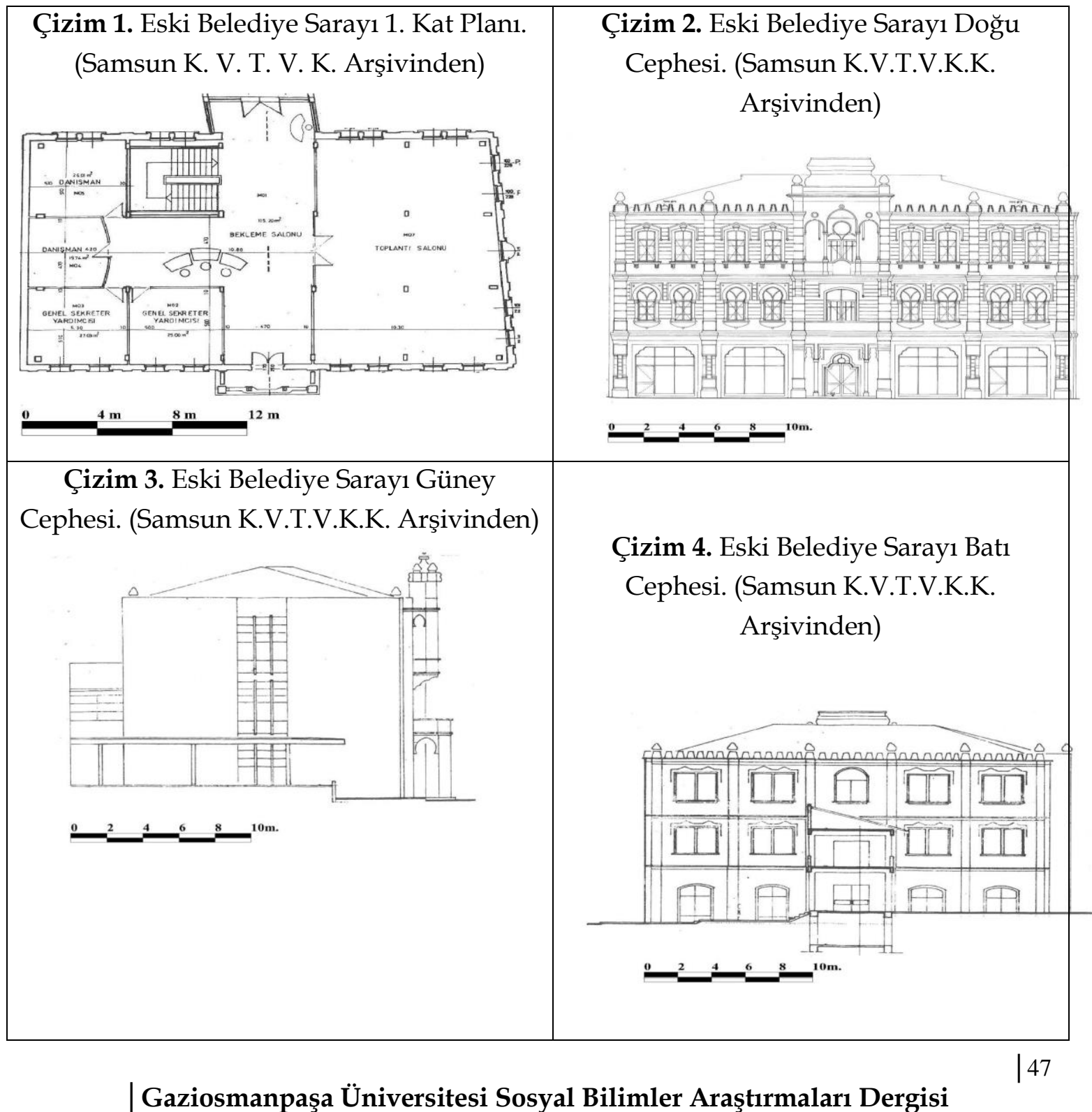

| Gaziosmanpaşa Üniversitesi Sosyal Bilimler Araştırmaları Dergisi 


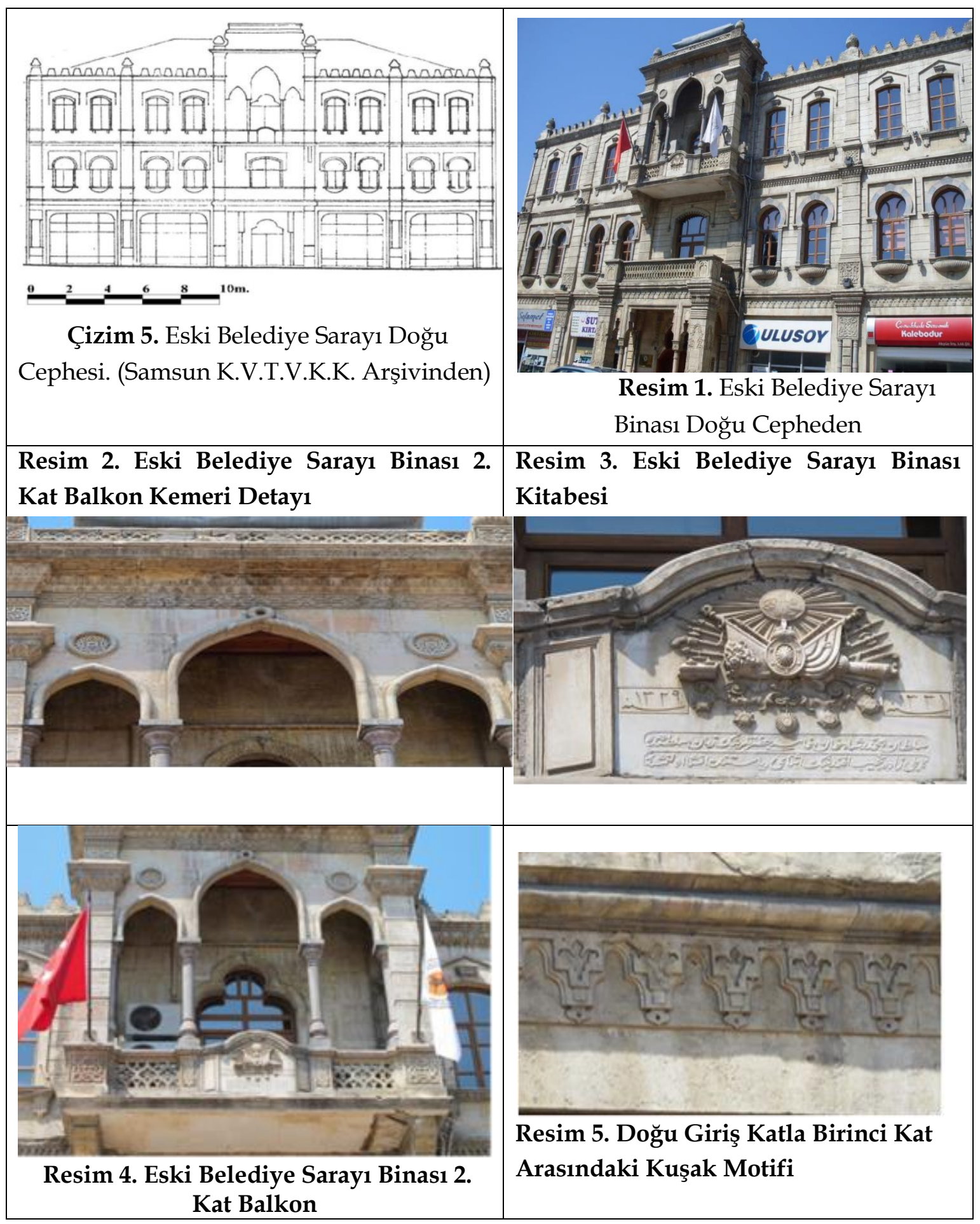

Gaziosmanpasa University Social Sciences Researches Journal 


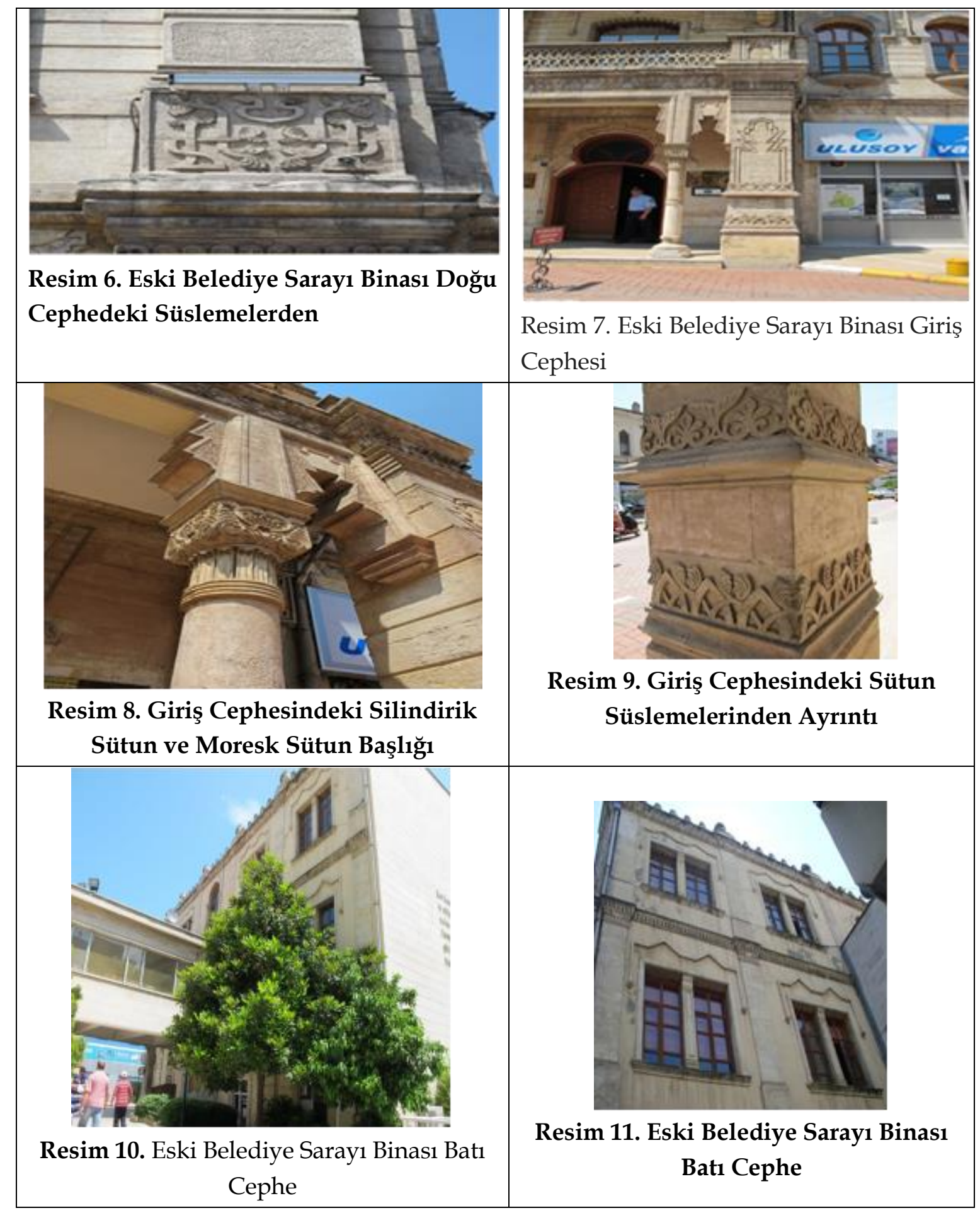

| Gaziosmanpaşa Üniversitesi Sosyal Bilimler Araştırmaları Dergisi 


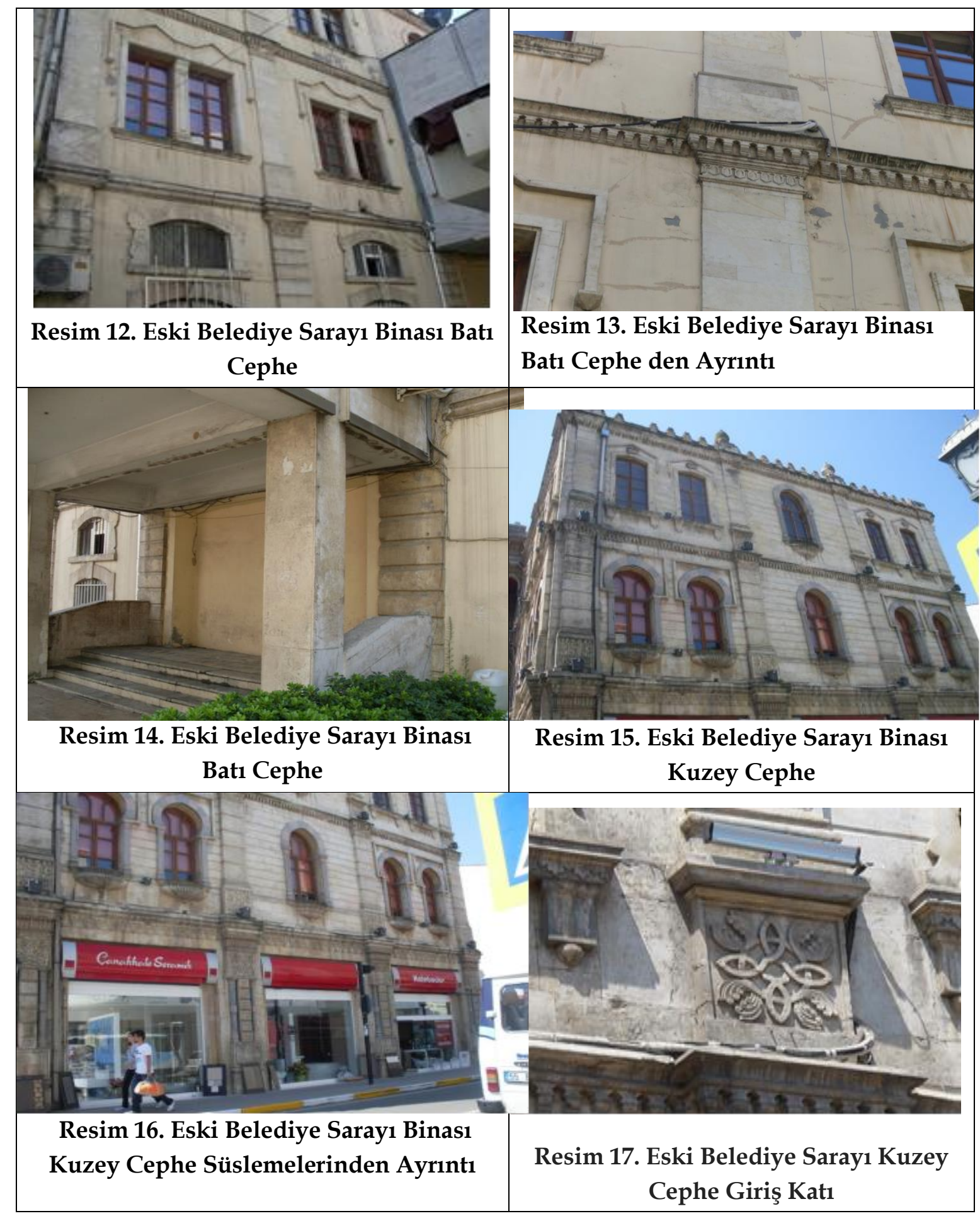

Gaziosmanpasa University Social Sciences Researches Journal 


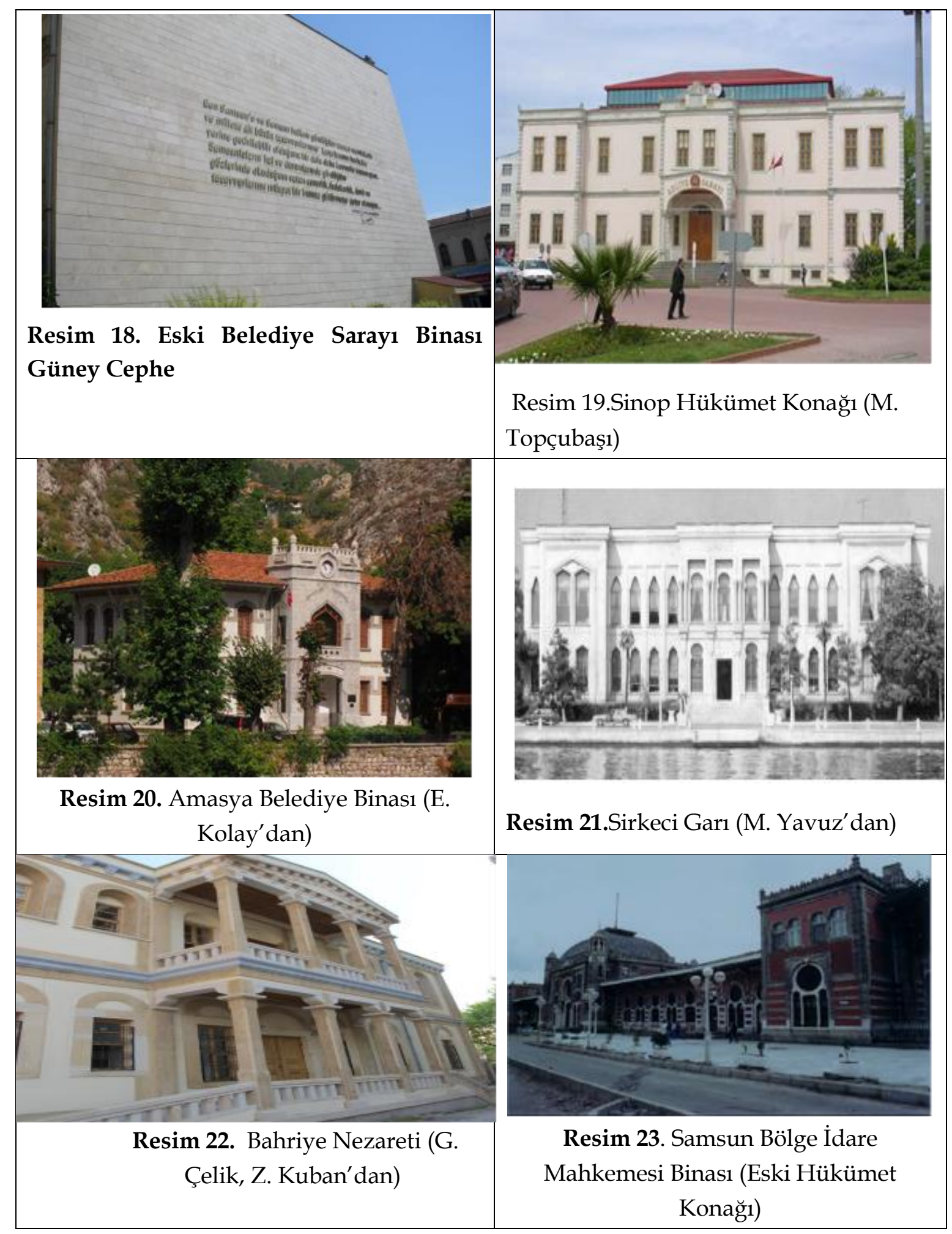

| Gaziosmanpaşa Üniversitesi Sosyal Bilimler Araştırmaları Dergisi 


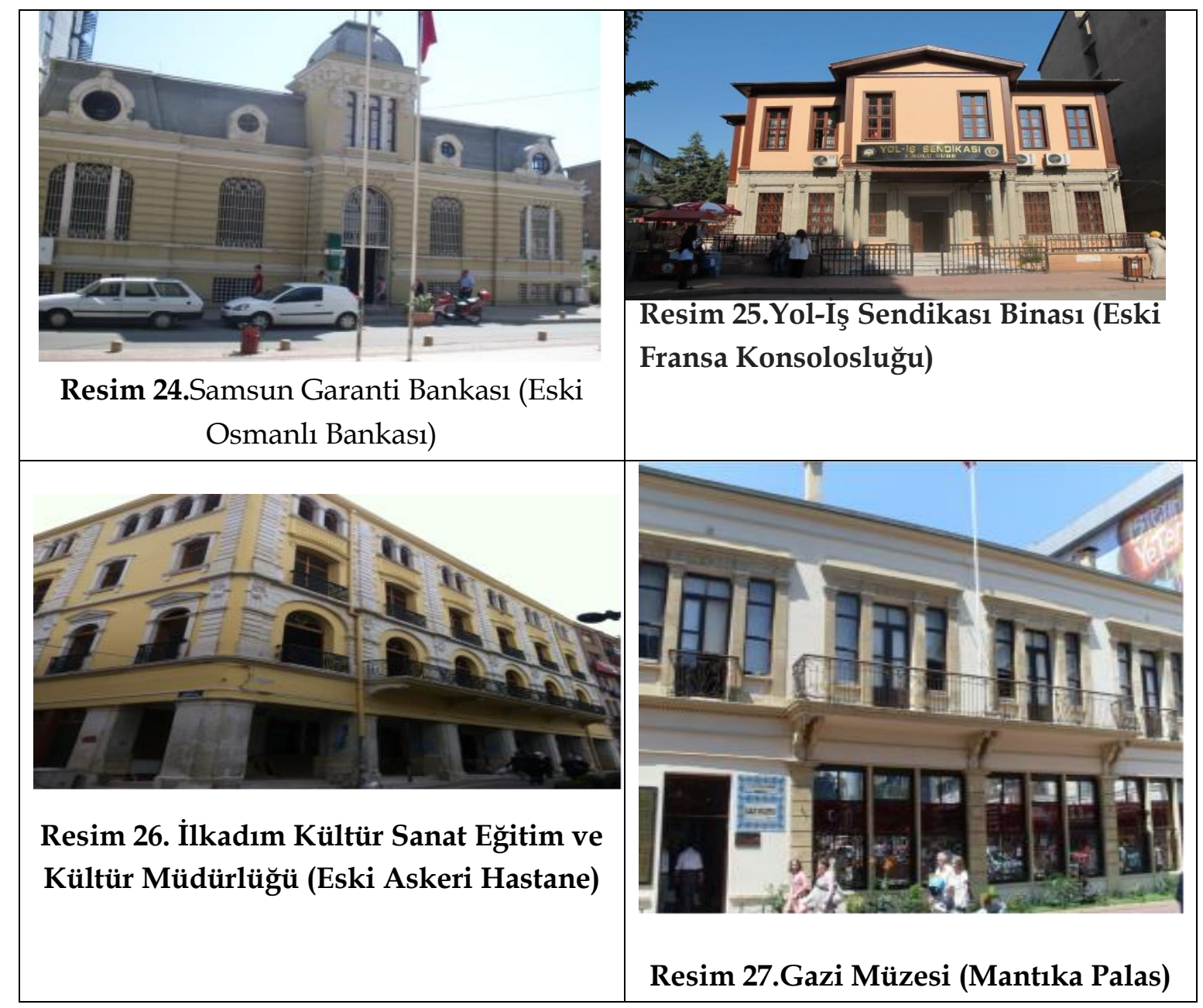

Gaziosmanpasa University Social Sciences Researches Journal 